\title{
Posouváme hranice kardiovaskulární prevence dál - první fixní trojkombinace antihypertenziv perindopril + amlodipin + indapamid v boji proti neuspokojivé kompenzaci hypertenze a reziduálnímu kardiovaskulárnímu riziku
}

I přes dosažený pokles kardiovaskulární (KV) mortality je kompenzace hypertenze i u pacientů s vysokým rizikem v ČR nedostatečná. I při kombinované antihypertenzní léčbě přetrvává reziduální KV riziko dané remodelací cév, hypertrofií levé komory a metabolickými rizikovými faktory. Nová fixní trojkombinace perindopril + amlodipin + indapamid, která bude brzy uvedena na český trh, prokázala silnou antihypertenzní účinnost, významný vliv na snížení celkové mortality pacientů a výsledky dokládají i lepší snášenlivost a vyšší adherenci k léčbě při podávání tří antihypertenziv $v$ jedné tabletě. Možnostem, jak posunout hranici KV prevence, se ve svých přednáškách na XXII. výročním sjezdu České kardiologické společnosti v květnu 2014 v Brně věnovali prof. MUDr. Renata Cífková, CSc. (1. LF UK a TN v Praze), prof. MUDr. Aleš Linhart, DrSc. (1. LF UK a VFN v Praze) a doc. MUDr. Michal Vrablík, Ph.D. (1. LF UK a VFN v Praze).

\section{Kompenzace hypertenze je neuspokojivá}

Úmrtnost na kardiovaskulární onemocnění (KVO) v ČR od roku 1985 klesá. Aplikace modelu IMPACT na českou populaci ukazuje, že se na poklesu úmrtnosti na ischemickou chorobu srdeční (ICHS) podilí více pokles tlaku krve (TK) v populaci než léčba hypertenze. Kontrola hypertenze je i u vysoce rizikových nemocných podle výsledků studie EUROASPIRE IV a nové české studie u pacientů po ischemických cévních mozkových príhodách (CMP) neuspokojivá.

Jak připomněla prof. Cífková, KVO se v roce 2012 v ČR podílela na celkové mortalitě ve $45 \%$ u mužů a $49 \%$ u žen. Od roku 1985 klesla standardizovaná úmrtnost na KVO zhruba o $52 \%$ u obou pohlaví. Přesto se naše země stále řadí mezi evropské státy s vysokým $\mathrm{KV}$ rizikem. Úmrtnost na ICHS je ovlivněna rizikovými faktory v populaci a léčebnou péćí. Výsledky v ČR porovnávající rok 1985 a 2007 ukázaly, že pokles počtu úmrtí na ICHS je možné vysvětlit z $52 \%$ ovlivněním rizikových faktorů a ze $43 \%$ zkvalitněním léčby (4 \% zůstávají nevysvětlena). Podobné

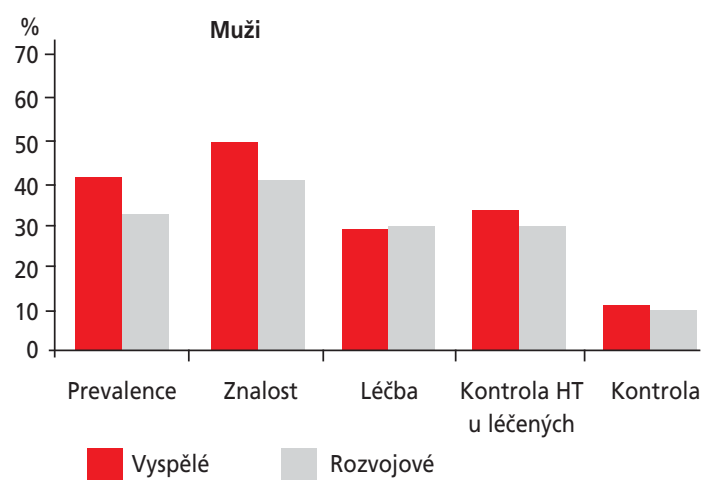

výsledky byly získány i v jiných rozvinutých zemích, jako je USA, Nový Zéland, Nizozemsko, Finsko, Itálie a Švédsko.

Pokud se týká jednotlivých rizikových faktorů, počet kuřáků klesl ze $49 \%$ na $34 \%$ u mužů, zatímco u žen zůstal nezměněn (27\%). Průměrný systolický TK (STK) významně klesl ze 135,8 na $132,5 \mathrm{~mm} \mathrm{Hg}$ u mužů a ze 131,6 na $126,7 \mathrm{~mm}$ Hg u žen. Podíl pacientů, kteří vědí o své hypertenzi, vzrostl ze $41 \%$ na $68 \%$ u mužů a z $59 \%$ na $71 \%$ u žen. Podíl hypertoniků, u nichž bylo dosaženo cílové hodnoty TK ( $<140 / 90 \mathrm{~mm} \mathrm{Hg})$, se zvýšil z 2,8 \% na $24,4 \%$ u mužù, a z 5,2 \% na $24,9 \%$ u žen. Zatímco kombinaci antihypertenziv užívalo v letech 1997-1998 (studie Czech post-MONICA) pouze zhruba $50 \%$ hypertoniků $(33,6 \%$ dvojkombinaci a $17,3 \%$ trojkombinaci), v období $2006-$ 2009 to bylo necelých $60 \%$ (33,4 \% dvojkombinaci a 25,6\% trojkombinaci). Screening hypertenze $v$ rámci studie Czech post-MONICA 2006-2009 ukázal, že $72 \%$ hypertonikư ví o svém onemocnění; medikamentózně léčeno je $60 \%$ a pouze $31 \%$ dosahuje TK $<140 / 90 \mathrm{~mm} \mathrm{Hg}$. Mezi hypertoniky, kteří nedosahují cílových hodnot TK, byl nižší podíl pacientů užívajících kombinaci antihypertenziv.

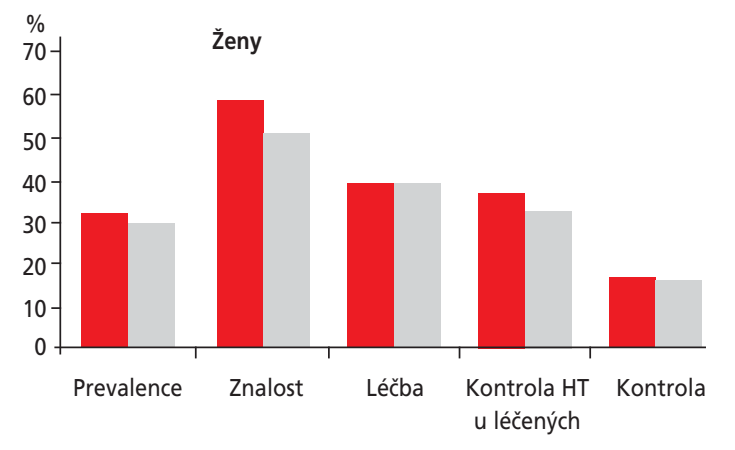

M. Pereira, N. Lunet, A. Azevedo, et al., Journal of Hypertension 27 (2009) 963-975.

Obr. 1 - Průměrná prevalence, znalost, léčba a kontrola hypertenze ve vyspělých a rozvojových zemích 
Systematická literární rešerše ukázala špatnou kompenzaci TK v 35 rozvinutých i rozvojových zemích (obr. 1). V USA a v Kanadě je nalézán nejvyšší podíl hypertoniků dosahujících cílového TK (až 65 \% v kanadské provincii Ontario), což Ize vysvětlit vyšším podílem diagnostikovaných pacientů a širším podáváním farmakoterapie.

Je otázkou, zda se situace liší v populaci vysoce rizikových pacientů po CMP. Do českého průzkumu provedeného ve dvou centrech (Plzeň a Praha) bylo zařazeno 423 nemocných po první ischemické CMP (průměrný věk 66,3 roku). Hypertenzi $v$ anamnéze mělo $83 \%$, průměrný TK činil 140,4/82,0 mm Hg. Při ambulantním vyšetření byla hypertenze zjištěna u $88,2 \%$ nemocných. $\boldsymbol{Z}$ těchto vysoce rizikových pacientů $93 \%$ o svém onemocnění vědělo, a z nich $96 \%$ bylo léčeno, ovšem pouze $45 \%$ léčených hypertoniků dosáhlo $\mathrm{TK}<140 / 90 \mathrm{~mm} \mathrm{Hg}$. Jak upozornila prof. Cífková, je to velmi nízké číslo, protože jde o pacienty, u nichž je dle standardu Evropské společnosti pro hypertenzi/Evropské kardiologické společnosti (ESH/ESC) doporučena antihypertenzní léčba i při STK 140-159 mm Hg. V této studii mělo $37 \%$ pacientů dokonce STK $\geq 160$ $\mathrm{mm} \mathrm{Hg}$. Podíl pacientů užívajících pouze monoterapii v léčbě hypertenze byl $31 \%$, dvojkombinaci $24 \%$, trojkombinaci $24 \%$, a kombinaci $\geq 4$ antihypertenziv $21 \%$.

Tyto výsledky potvrzuje i studie EUROASPIRE IV provedená v roce 2012, která přináší porovnání pacientů s manifestní ICHS v řadě evropských zemí. V ČR o své hypertenzi vědělo $86 \%$, což je ve shodě s průměrem všech zemí, v nichž byla provedena EUROASPIRE IV (87 \%). Cílových hodnot TK $(<140 / 90$ mm Hg a $<140 / 80$ mm Hg u diabetiků) dosáhlo u nás pouze $51 \%$ pacientů, což je méně než průmèr ve studii EUROASPIRE IV (57\%).

\section{Reziduální kardiovaskulární riziko Ize snížit}

I při kombinované antihypertenzní léčbě přetrvává reziduální KV riziko. Jeho snížení je možné dosáhnout včasnou a intenzivní léčbou zahrnující kompenzaci dalších rizikových faktorů. Důkazy o snížení morbidity a mortality podporuji volbu antihypertenzní kombinace ACEI + dihydropyridinový blokátor Ca kanálů $(B K K)$ a velmi silná data prinesly také studie s kombinací perindopril + indapamid, zejména díky přiznivému vlivu těchto antihypertenziv na regresi cévní remodelace a hypertrofie levé komory, koronární rezervu a metabolické parametry.

Post-hoc analýza studie EUROPA ukázala, že přidání perindoprilu $\mathrm{k}$ BKK snížilo během pěti let relativní KV riziko (KV úmrtí, infarkt myokardu, zresuscitovaná srdeční zástava) o 35 \%. Z hlediska absolutní incidence to znamená, že za pět let sledování nemělo KV příhodu 92,5 \% pacientů léčených BKK a 95,1 \% léčených kombinací BKK + perindopril. Jak uvedl prof. Linhart, i přes zjevný přínos kombinované antihypertenzní léčby přetrvává u hypertoniků významné reziduální riziko, které bylo prokázáno i v dalších studiích (SHEP, Syst-Eur, PROGRESS) (obr. 2). Je také známo, že léčení hypertonici mají významně vyšši riziko $K V$ přihod než osoby se stejným TK bez léčby. Možné prríčiny nedostatečného účinku antihypertenzní léčby na snížení KV rizika zahrnují akumulaci jiných rizikových faktorů, nefyziologic- ké účinky některých antihypertenziv a pozdní a málo agresivní léčbu.

Současná teorie rozvoje hypertenze popisuje kontinuum endoteliální dysfunkce - vaskulární dysfunkce - zvýšení TK - poškození cílových orgánů. Z ní vyplývá nutnost regrese cévní remodelace (poměr media/lumen) na úrovni malých rezistenčních arterií, která byla prokázána u perindoprilu. Studie PREVENT prokázala prínos amlodipinu z hlediska tloušt'ky intimy a medie. Studie CAFE jako podstudie ASCOT ukázala podobný pokles brachiálního STK při léčbě kombinací atenolol + thiazidové diuretikum i amlodipin + perindopril, ale významně větší pokles centrálního STK u kombinace amlodipin + perindopril. To je významné, jak připomněl prof. Linhart, z hlediska hypertrofie levé komory. Regrese hypertrofie levé komory byla prokázána při léčbě perindoprilem. Ve studii LIVE, která porovnávala léčbu hypertenze indapamidem a enalaprilem, zajistil indapamid při stejném poklesu krevního tlaku významně větší snížení tloušt'ky stěn a velikosti levé komory. Kombinace perindopril + indapamid vedla ke snížení indexu hmotnosti levé komory o 13,6 g/m² v porovnání s $3,9 \mathrm{~g} / \mathrm{m}^{2}$ při léčbě enalaprilem. Ve studii PICXEL zajistila kombinace perindopril + indapamid u dosud neléčených hypertonikư významné zvýšení koronární rezervy po šesti měsících léčby z 2,1 na 4,9 $\mathrm{ml} / \mathrm{min} / \mathrm{g}$.

Antihypertenzní léčba se může lišit i ve svém vlivu na metabolické parametry. Ve studii ASCOT léčba amlodipinem + perindoprilem zajistila významně nižší incidenci diabetu v porovnání s kombinací atenolol + thiazidové diuretikum. Významný rozdíl mezi těmito kombinacemi antihypertenziv ve prospěch amlodipinu + perindoprilu byl zjištěn také z hlediska hodnoty HDL cholesterolu. Již zmíněná studie LIVE prokázala absenci nepríznivého vlivu indapamidu na metabolické parametry (glykemie, koncentrace triglyceridů, celkový cholesterol, hmotnost).

Význam vzájemné interakce všech KV rizikových faktorů potvrdila studie MRFIT, která ukázala amplifikaci vlivu jednotlivých KV rizikových faktorů na mortalitu. Nutnost multifaktoriální intervence rizikových faktorů dokládají výsledky studie ASCOT, které zdůrazňují, že volbou vhodné kombinace antihypertenziv a ovlivněním ostatních rizikových faktorů je možné zabránit většímu počtu úmrtí našich nemocných.

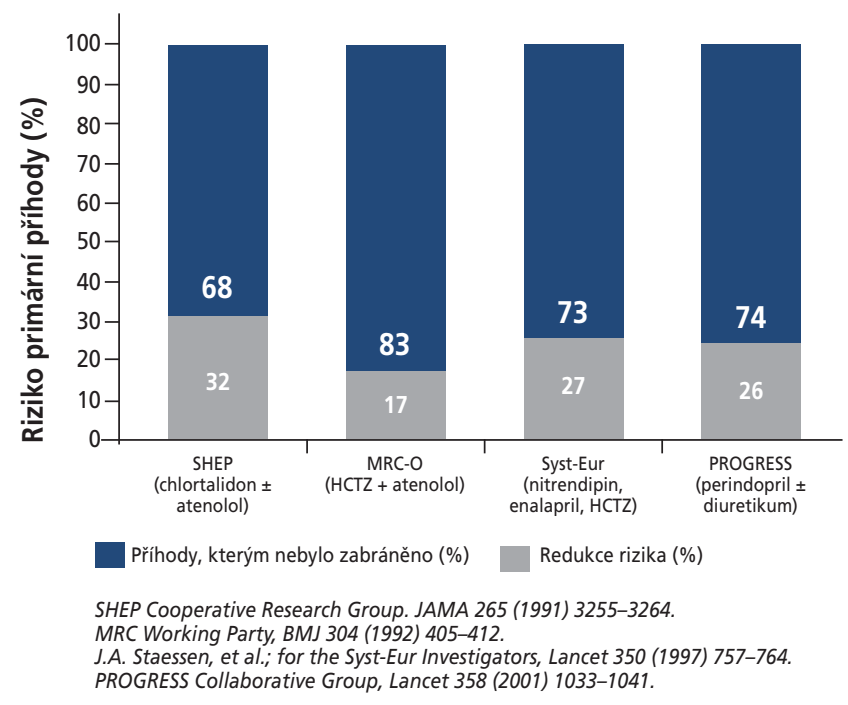

Obr. 2 - Reziduální kardiovaskulární riziko u léčeného hypertonika 


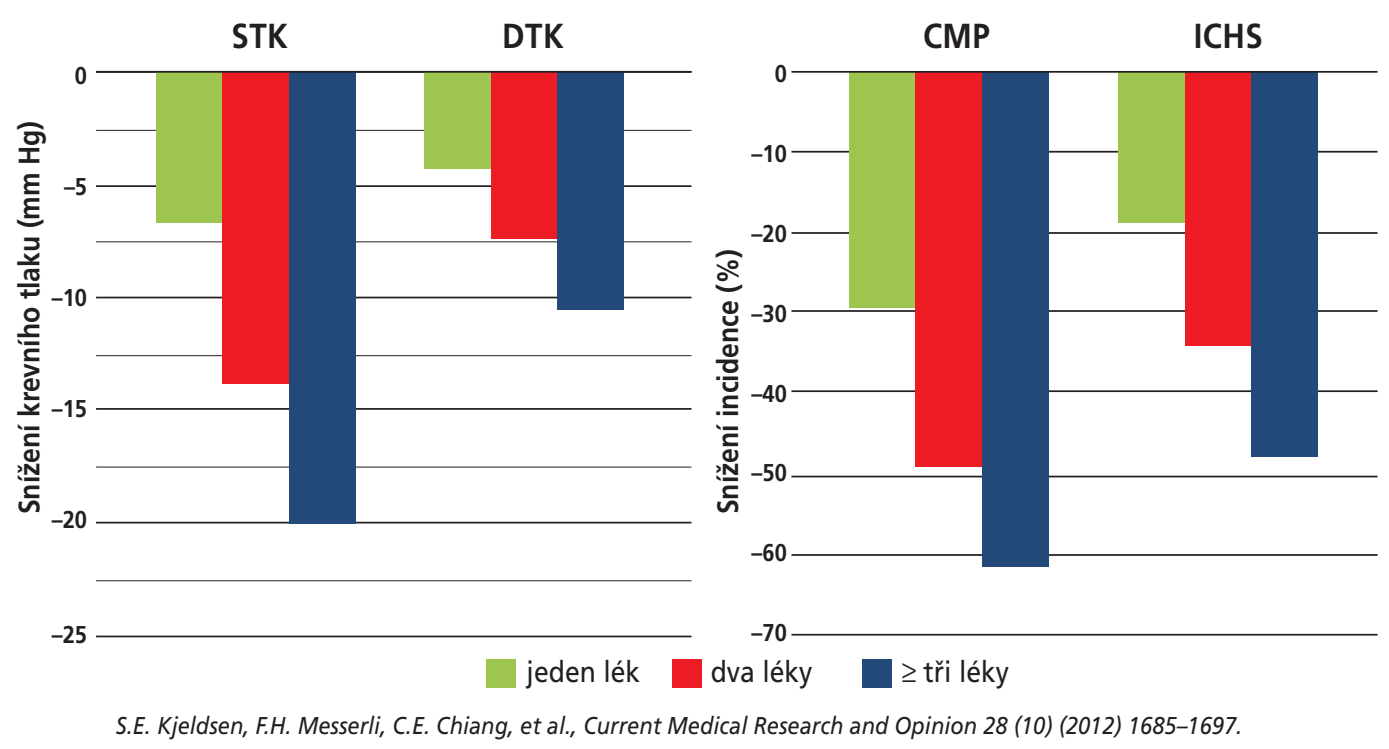

Obr. 3 - Trojkombinace antihypertenziv posouvají hranice kontroly tlaku krve a kardiovaskulární ochrany dále.

CMP - cévní mozková př́hoda; DTK - diastolický tlak krve; ICHS - ischemická choroba srdeční; STK - systolický tlak krve.

\section{Nová fixní trojkombinace perindopril + amlodipin + indapamid účinně snižuje krevní tlak a mortalitu pacientů, příznivě ovlivňuje metabolické parametry a zvyšuje snášenlivost $a$ adherenci $k$ léčbě}

U $75 \%$ hypertoniků je nutná kombinace antihypertenziv. Základem kombinace by měl být blokátor RAS (preferenčně $A C E I)$, následovaný $B K K$ a diuretikem (preferenčně indapamidem). Adherence nemocných $k$ léčbě je nepřímo úměrná počtu tablet, proto jsou výhodné fixní kombinace. Nová fixní trojkombinace perindopril + amlodipin + indapamid, která bude brzy uvedena na český trh, má nejen teoretické předpoklady, ale i pádné klinické důkazy dokládajíci její místo $v$ léčbě hypertenze a prevenci $K V$ chorob.

Režimová opatření (dieta a pohybová aktivita) jsou základem léčby všech hypertoniků. $V$ naprosté většině případů je nutné tyto intervence kombinovat s farmakoterapií, a to v $75 \%$ prípravky z více terapeutických tříd. Z morbi-mortalitního hlediska jsou ze sedmi tříd antihypertenziv nejvíce doporučovanými kombinacemi blokátory RAS + BKK, blokátory RAS + thiazidová a thiazidům podobná diuretika a BKK + thiazidová a thiazidům podobná diuretika. Je prokázáno, že podávání kombinace od zahájení léčby snižuje v porovnání s monoterapií riziko přerušení léčby o 73 \%. Fixní kombinace snižuje riziko non-compliance v porovnání s volnou kombinací o $24 \%$. Přesto, jak zdůraznil doc. Vrablík, 60 \% pacientů léčených dvojkombinací antihypertenziv nemá kompenzovaný TK. Úspěšná kontrola hypertenze vyžaduje často více než dva léky (obr. 3). Nepříznivým faktem ovšem je, že při zvyšujícím se počtu předepsaných lékư klesá adherence $k$ léčbě. Non-adherence přitom prokazatelně zvyšuje výskyt fatálních i nefatálních KV příhod.

Z velkého množství randomizovaných klinických studií pouze tři zaměřené na kombinovanou léčbu prokázaly účinné snížení KV sledovaných parametrů. Významné snížení KV mortality prokázala studie ADVANCE při podávání kombinace perindopril + indapamid u diabetikư 2. typu, studie ASCOT při kombinaci amlodipin \pm perindopril u rizikových hypertoniků a HYVET pr̆i kombinaci indapamid ะ perindopril u starších hypertoniků. Studie PICASSO, provedená ve velké kohortě hypertoniků sledovaných v "reálné klinické praxi", navíc ukázala, že kombinace perindopril-indapamid vede kromě snížení TK také ke zlepšení metabolických parametrů, jako je pokles celkového cholesterolu, triglyceridů, glykemie a zvýšení HDL cholesterolu.

Na český trh bude brzy uvedena fixní trojkombinace perindoprilu $s$ amlodipinem a indapamidem $v$ jedné tabletě. Antihypertenzní účinnost této trojkombinace antihypertenziv byla hodnocena ve studii PIANIST, která zahrnovala 4731 pacientů $s$ nekontrolovanou hypertenzí (průměrně $160,5 / 93,8$ mm Hg) s průměrnou délkou trvání onemocnění 11,9 roku. Průměrný věk pacientů byl 63,8 roku a většina z nich měla další rizikové faktory: $64 \%$ dyslipidemii, $45 \%$ obezitu, $37 \%$ kouření, $36 \%$ ICHS a $33 \%$ diabetes. Pacienti byli převedeni na fixní kombinaci $10 \mathrm{mg}$ perindoprilu + 2,5 mg indapamidu + 5/10 mg amlodipinu, která byla podávána po dobu čtyř měsíců. Ve skupině s nekontrolovanou hypertenzí při kombinaci inhibitor RAS + hydrochlorothiazid dosáhlo po prevedení na hodnocenou fixní trojkombinaci cílových hodnot TK 92 \% pacientů. Zajímavý pohled na účinnost léčby trojkombinací perindopril + indapamid + BKK přináší post-hoc analýza studie ADVANCE. Vyplývá z ní, že tato trojkombinace zajištuje nejen vysoce účinnou kontrolu hypertenze, ale vede zejména k významnému poklesu celkové mortality o $28 \%$ a KV mortality o $24 \%$ oproti léčbě založené na BKK bez ACEI a diuretika. Navíc se ukázalo, že trojkombinace perindopril + amlodipin + indapamid zlepšuje snášenlivost antihypertenzní léčby. Při kombinaci ACEI s BKK a diuretikem také můžeme počítat se snížením výskytu edému spojeného s BKK při podávání perindoprilu, snížením výskytu kašle navozeného ACEI při podávání amlodipinu a zlepšením metabolické kontroly při podávání indapamidu. Nová a první fixní trojkombinace antihypertenziv vstupuje do klinického použití sice s nepřímými, ale dostatečnými důkazy potvrzujícími nejen výbornou antihypertenzní účinnost, ale také s podporou údajů o příznivém ovlivnění prognózy takto léčených pacientů.

MUDr. Zuzana Zafarová 